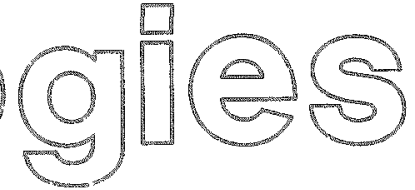

$G A-A--18870$

DE87 013998

\title{
ANNULAR CORE \\ FOR MODULAR HIGH-TEMPERATURE GAS-COOLED REACTOR (MHTGR)
}

\author{
by \\ R. F. TURNER, A. M. BAXTER, O. M. STANSFIELD, \\ and R. E. VOLLMAN
}

AUGUST 1987 


\section{DISCLAIMER}

This report was prepared as an account of work sponsored by an agency of the United States Government. Neither the United States Government nor any agency thereof, nor any of their employees, makes any warranty, express or implied, or assumes any legal liability or responsibility for the accuracy, completeness, or usefulness of any information, apparatus, product, or process disclosed, or represents that its use would not infringe privately owned rights. Reference herein to any specific commercial product, process, or service by trade name, trademark, manufacturer, or otherwise, does not necessarily constitute or imply its endorsement, recommendation, or favoring by the United States Government or any agency thereof. The views and opinions of authors expressed herein do not necessarily state or reflect those of the United States Government or any agency thereof. 


\section{DISCLAIMER}

This report was prepared as an account of work sponsored by an agency of the United States Government. Neither the United States Government nor any agency Thereof, nor any of their employees, makes any warranty, express or implied, or assumes any legal liability or responsibility for the accuracy, completeness, or usefulness of any information, apparatus, product, or process disclosed, or represents that its use would not infringe privately owned rights. Reference herein to any specific commercial product, process, or service by trade name, trademark, manufacturer, or otherwise does not necessarily constitute or imply its endorsement, recommendation, or favoring by the United States Government or any agency thereof. The views and opinions of authors expressed herein do not necessarily state or reflect those of the United States Government or any agency thereof. 


\section{DISCLAIMER}

Portions of this document may be illegible in electronic image products. Images are produced from the best available original document. 


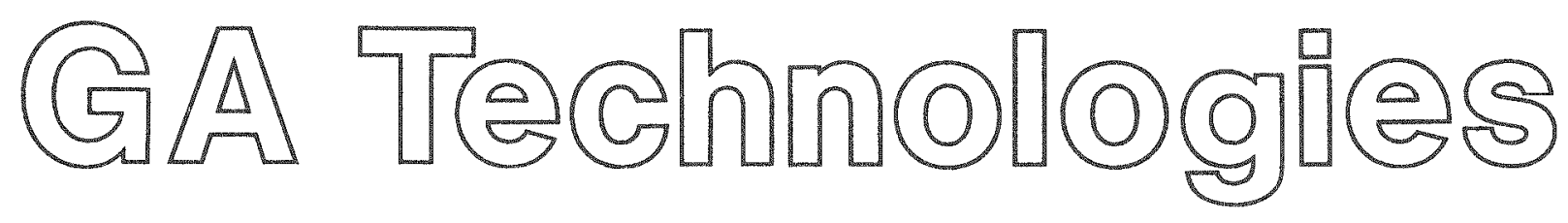

GA-A18870

\title{
ANNULAR CORE \\ FOR MODULAR HIGH-TEMPERATURE GAS-COOLED REACTOR (MHTGR)
}

\author{
by \\ R. F. TURNER, A. M. BAXTER, O. M. STANSFIELD, \\ and R. E. VOLLMAN
}

This is a preprint of a paper to be presented at the Post-Conference Seminar on Small and Medium Sized Nuclear Reactors of the 9th international Conference on Structural Mechanics in Reactor Technology, August 24-26, 1987, Lausanne, Switzerland and to be published in the Proceedings.

Work supported by

Department of Energy

Contract DE-AC03-84SF11963

GA PROJECT 7800

AUGUST 1987 
ANNULAR CORE FOR MODULAR HIGH TEMPERATURE GAS-COOLED REACTOR (MHTGR)

R. F. Turner, A. M. Baxter, O. M. Stansfleld, and R. E. Vollman

[GA Technologies Inc., San Diego, Calffornia, USA]

\section{Abstract}

The active core of the $350 \mathrm{MW}(t)$ MHTGR is annular in configuration, shaped to provide a large external surface-to-volume ratio for the transport of heat radially to the reactor vessel in case of a loss of coolant flow. For a given fuel temperature limit, the annular core provides approximately $40 \%$ greater power output over a typical cylindrical configuration. The reactor core is made up of columns of hexagonal blocks, each $793-\mathrm{mm} \mathrm{hlgh}$ and $360-\mathrm{mm}$ wide. The active core is $3.5 \mathrm{~m}$ in $0 . d ., 1.65 \mathrm{~m}$ in $1 . d$. , and $7.93-\mathrm{m}$ tall. Fuel elements contain TRISOcoated microspheres of $19.8 \%$ enriched uranium oxycarbide and of fertile thorfum oxide. The core is controlled by 30 control rods which enter the inner and outer side reflectors from above.

\section{Keywords}

Gas-cooled reactor

High temperature reactor

Core design

Annular core

Coated fuel particles

Modular reactor

\section{Introduction}

The utility/user requirements for the MHTGR design call for fundamental changes in the traditional approach toward attaining the economic and safety goals of the plant (Ref. 1). The safety and investment protection goals are to be met at the plant exclusion area boundary without any need for sheltering or evacuation. The safety goals are to be achieved without any reliance upon complex active systems, such as pressurized secondary containment or active heat removal circuits (Ref. 2).

A significant feature of the Standard MHTGR design is its capability for passive decay heat rejection. In the unlikely event that both the normal and shutdown cooling systems are unavailable, decay heat must be rejected by radiation, conduction, and natural convection from the core to the reactor vessel wall and outward to air-cooled panels within the reactor cavity structure. These passive decay heat rejection requirements influence the shape and size of the reactor core. A relatively tall core with a high surface-to-volume ratio provides for acceptable fuel temperatures during a total loss of coolant flow, whether the primary coolant system is pressurized or depressurized. At the rated core thermal power of $350 \mathrm{MW}$, the peak fuel temperature is approximately $1600^{\circ} \mathrm{C}$ for the most severe loss-of-forced circulation case. This temperature is well within the limits for high retention of fission products by the all-ceramic coated fuel particles (Ref. 3). 


\section{Reactor Core Configuration}

The reactor core and the surrounding graphite neutron reflectors are supported within a steel reactor vessel. The configuration is shown in Fig. 1 in both an elevation view and a plan view. The restraining structures within the reactor vessel are a steel and graphite core support structure at the bottom and a metallic core barrel around the periphery of the side reflectors.
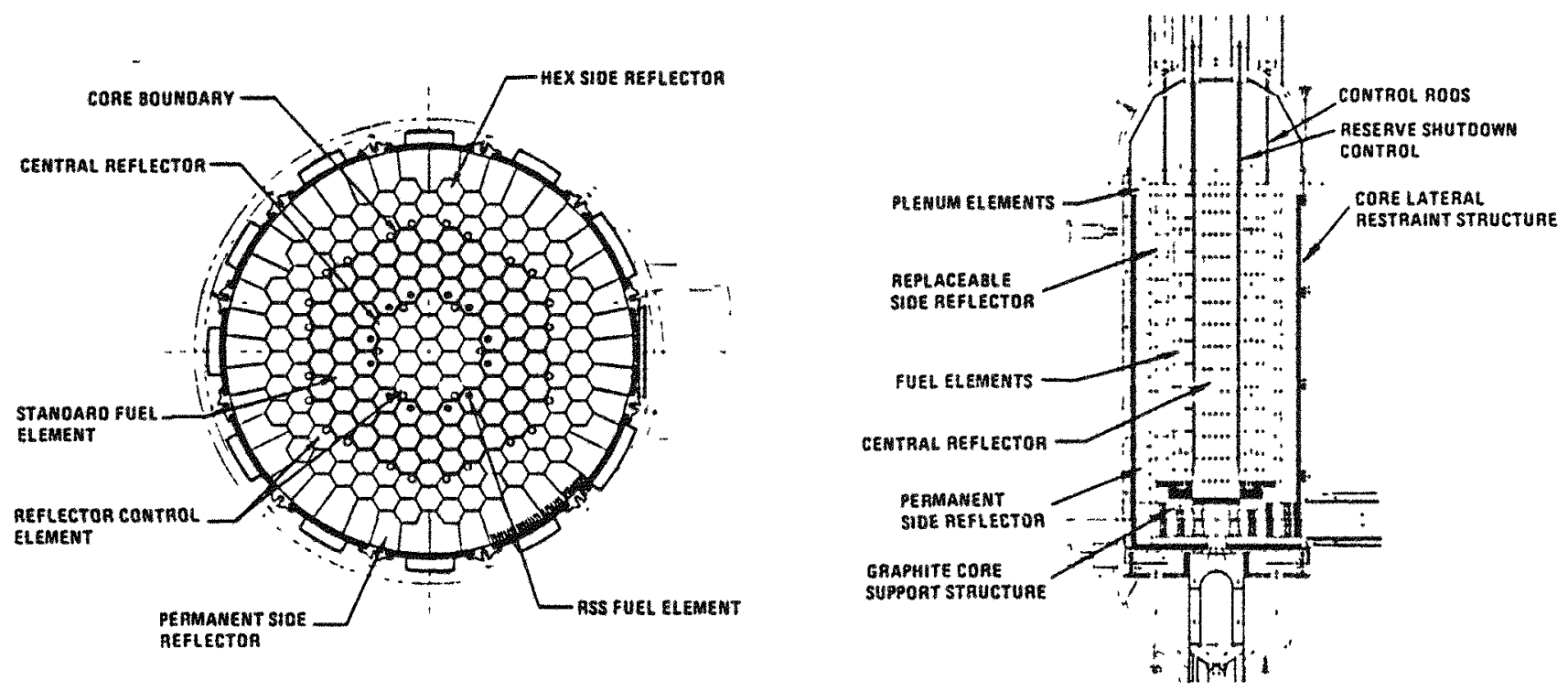

Fig. 1: Reactor Core Configuration

The annular active core is $3.50 \mathrm{~m}$ in $0 . d ., 1.65 \mathrm{~m}$ in $1 . d$. , and $7.93-\mathrm{m}$ (10 fuel elements) tall. The 660 fuel elements, each a hexagonal prism $360-\mathrm{mm}$ wide by $793-\mathrm{mm}$ tall, are arrayed in columns within the active core. Key core design parameters are given in Table 1. The primary coolant is helfum which flows downward through the core.

$\begin{array}{lr}\text { Core power, } M W(t) & 350 \\ \text { Core power density, } \mathrm{MW} / \mathrm{m}^{3} & 5.9 \\ \text { Core outlet helium temperature, }{ }^{\circ} \mathrm{C} & 690 \\ \text { Core refueling interval, yr } & 1.6 \\ \text { Fuel element lifetime, yr } & 3.2 \\ \text { Fuel burnup (Average), MWd/Tonne } & 100,000\end{array}$

Table 1: Core Design Parameters 
Neutron control is provided by 30 control rods which enter channels in the columns of replaceable elements immediately adjacent to the active core. Six of the control rods are in the central reflector, and the remaining 24 are in the outer reflector. In addition to the control rods, there are 12 reserve shutdown control channels within the active core which can recelve boron-graphite pellets as the independent-shutdown absorber. The reserve shutdown pellets are contained in hoppers located above the active core and can be released manually.

The fuel element are removed during shutdown by a handing machine which enters the reactor vessel through the control rod penetrations.

\section{Fuel Elements}

The fuel elements are right hexagonal prisms of the same size and shape as the Fort St. Vrain HTGR elements. The fuel element components are shown in Fig. 2. The graphite block is machined from Great Lakes Carbon $\mathrm{H}-451$ grade material.

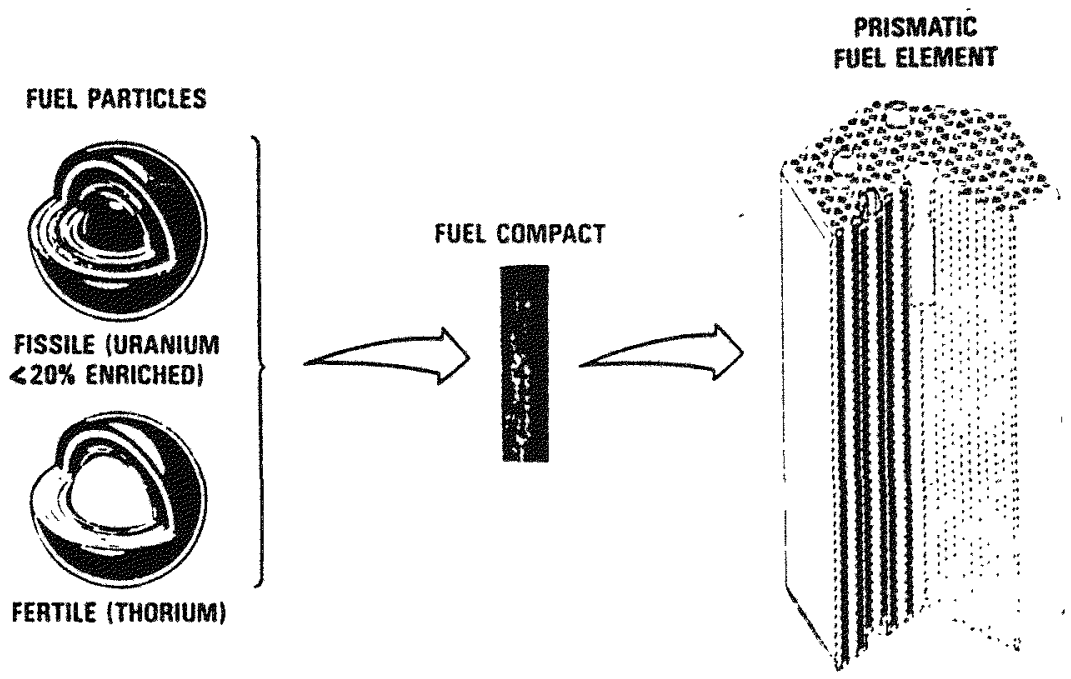

Fig. 2: Fuel Element Components

The fuel element employs low-enriched uranium and thorium (LEU/Th) materfals. The fissile fuel is a two-phase mixture of $19.8 \%$ enriched $\mathrm{VO}_{2}$ and $\mathrm{UC}_{2}$, usually referred to as UCO, having an oxygen-to-uranium ratio of 1.7 in fresh fuel. The fertile fuel is $\mathrm{ThO}_{2}$. Both fertile and fissile fuels are in the form of dense microspheres coated with TRISO coatings to retain fission products. The coated fissile and fertile particles are intimately blended and bonded together by a carbonaceous binder into fuel compacts. Figure 2 illustrates the TRISO coating concept and how the fuel is packaged within the fuel element. The fissile fuel kernel diameter is 350 microns, and the fertile kernel diameter is 500 microns. The coating thickness is about $200 \mathrm{microns}$ (Ref. 4).

The fuel and coolant holes are located in parallel through the length of the element. The standard fuel element contalns a continuous array of fuel and coolant holes in a regular triangular array of two fuel holes per one coolant hole. The six corner holes contain lumped burnable poison compacts. 
At each element-to-element interface in a column, there are four dowel/socket connection which provides alignment of coolant channels. A 35-mm diameter fuel handling hole, located at the center of the element, extends down about one-third of the height, with a ledge where the grapple of a fuel handing machine engages.

The fuel compacts, contained in-the fuel holes, are 12.5-mm dfameter by $50-\mathrm{mm}$ long. Each fuel compact contains fissile, fertile, and graphite shim particles bonded by a carbonaceous matr1x. A total of 15 fuel compacts normally make up a stack within a fuel hole. The fuel quality and in-service performance limits are summarfzed in Table 2 for the fuel compacts. The as-manufactured fuel quality has been demonstrated to this level in both the Federal Republic of Germany (for spheres) and the U.S.A.

\section{AS-MANUFACTURED FUEL QUALITY:}

- Missing buffer fraction

$\leq 5.0 \times 10^{-5}$

- SiC coating defect fraction

$\leq 5.0 \times 10^{-5}$

- Heavy-metal contamination fraction

$\leq 1.0 \times 10^{-5}$

\section{FUEL PERFORMANCE:}

- Average in-service coating failure $\quad 55.0 \times 10^{-5}$ fraction

- Average incremental coating fallure $\quad \leq 1.5 \times 10^{-4}$ fraction during accident (exposed kerne1)

Table 2: MHTGR Fuel Performance and Fuel Qual1ty Requirements

\section{Reflector Elements}

The replaceable reflector elements are graphite blocks of the same shape, size, and matertal as the fuel elements. The top and bottom reflector elements contain coolant holes to match those in the active core. All reflector elements have dowel connection for alignment.

\section{Core Neutronics}

The low-enriched uranium and thorium fuel cycle has been selected to meet the requirements of using nonweapons grade ( $220 \%$ enriched) uranium. The thorium is included to facilitate zoning of power distributions in both radial and axial directions while using a single uranium enrichment. The thermal performance of fuel elements is essentially the same for fully enriched fuel, as demonstrated in the Fort St. Vrain reactor, or for the lower enriched cycle in the MHTGR. 
The core reactivity is controlled by a combination of fixed lumped burnable poison, movable poison and a negative temperature coefficient. The number and location of the 30 top entry control rods and the diverse reserve shutdown control have been specified to assure that the reactor thermal power is controlled both for normal and off-normal conditions. The radial thickness of the active core annulus was specified on the basis of assuring that the control rod worths of the reflector-located rods would meet all shutdown and operating control worth requirements. The choice of reflector control rods was made to assure that the control rod integrity is maintained during passive decay heat removal events.

The evaluation of control rod and reserve shutdown control. reactivity worths under both hot and cold condftions show that a large margin exists between the maximum reactivity requirements and the calculated rod worths. The reactivity and rod worth values are shown in Table 3 .

A design criterion for the core is that the reactivity feedback characteristics shall limit the core temperatures. The active-core power coefficlents are strongly negative. The core isothermal temperature coefficlent is about $-7 \times 10^{-5} /{ }^{\circ} \mathrm{C}$ at the beginning-of-cycle conditions and about $-4 \times 10^{-5} /{ }^{\circ} \mathrm{C}$ at the end-of-cycle for the typical moderator operating temperature of $700^{\circ} \mathrm{C}$. The power coefficient becomes rapidly more negative at higher temperatures. The high heat capacity of the graphite core and the negatlve temperature coefficlent results in a core which is very stable to changes in reactivity.

\begin{tabular}{rr} 
Beginning & End \\
of Cycle & of Cycle \\
\hline
\end{tabular}

Reactivity to Control: (\% $\% \rho)$

Core operating excess reactivity

$1.0 \quad 0.5$

Temperature effect (hot to cold)

$4.8 \quad 1.2$

Xenon decay

$3.7 \quad 3.7$

Other fission product decay

$0 \quad 1.3$

Shutdown and uncertainty

$2.0 \quad \underline{2.0}$

Total

$11.5 \quad 8.7$

Worths of Control Poisons: (\% $\Delta \rho)$

24 outer control rods

$8.1 \quad 11.0$

24 outer plus 6 inner control rods

$16.8 \quad 20.2$

Reserve shutdown control

$10.1 \quad 11.3$

$\begin{array}{lll}\text { All control rods and RSC } & 30.4 & 35.7\end{array}$

Table 3: Reactivity and Control Rod Worths

\section{Core Performance Characteristics}

The performance of the MHTGR core is measured primarily by the degree of retention of fission products within the coated fuel particles. The MHTGR design provides for a significant advancement in the containment concept for power plants 
(Ref. 3). The traditional philosophy of metal clad fuel systems for guarding against cladding failures at relatively low temperatures is not applicable to the MHTGR. Even for the most severe events for the MHTGR, the particle coatings contain the fission products at the source, not after some dispersal in a reactor bullding. The number of individual coated particles in a reactor core is about 1010 units. Furthermore, the particle-containment integrity is monitored throughout normal reactor operations by sampling the low level of fission products in the primary coolant.

During normal steady-state power operations, the fuel in the MHTGR operates at temperatures below $1250^{\circ} \mathrm{C}$ and fluences below $5.5 \times 10^{25} \mathrm{n} / \mathrm{m}^{2}$ (E)29fJ). The maximum heavy metal burnups are $25 \%$ and $3.5 \%$ FIMA for the fissile and fertile coated particles, respectively. Fuel performance models have been developed to quantify the integrity of the TRISO coated particles during both normal operation and design basis accldents (Ref. 4). The performance models for the fuel particles have been correlated with tests carried out in the USA, the FRG, and the UK confirming the integrity to fractions less than $5 \times 10^{-5}$ failure during normal operation and less than $1.5 \times 10^{-4}$ during heat-up events to a least $1600^{\circ} \mathrm{C}$ fuel temperatures.

The performance of graphite components in the core has been evaluated by a probabilistic approach which takes account of the volume-related distribution of materfal propertles and the time-dependent accumulation of strains (Ref. 5). Stress criterla have been developed by this approach which allows some local cracking of graphite elements with no effect on the nuclear, thermal, or fission product retention characteristics of the core.

\section{Conclusions}

The annular core design for the MHTGR provides for approximately $40 \%$ greater output over a cylindrical core, and a capability for maintaining fuel temperatures at levels which limit the failures of coated fuel particles to below $5 \times 10^{-5}$ fraction during normal operation and below $1.5 \times 10^{-4}$ during any licensing basis events. The core shape, as a tall annular cylinder, is directly influenced by the requirements to remove heat. Emphas is has been shifted from an external containment bullding to a coated-particle containment for the ultimate protection against loss-of-forced-circulation events.

The fuel element design is basically that of the Fort St. Vrain reactor, but with low enriched uranium ( $\leq 19.8 \%$ ) used instead of highly enriched uranium. All of the materials in the core are graphite or refractory ceramic.

The core is designed to be hlghly stable neutronically, with safe (negative) power coefficlents at all reactor temperatures.

\section{$\underline{\text { References }}$}

1. Dean, R. A., and T. A. Johnston, "Development of the Modular HTGR in the USA," presented at ENC-6, Geneva, June 1, 1986.

2. "Conceptual Description Report, 4 × 350 MW( $t)$ Modular HTGR Plant," issued by Bechtel National, Inc., Report No. HTGR-86-118, October 1986.

3. Northup, T. E., O. Stansfield, and H. Stewart, "An Assessment of the Modular HTGR Containment System," Paper at 22nd Intersociety Energy Conversion Engineering Conference (IECEC), Philadelphia, PA, August 10-14, 1987. 
4. Stansfield, 0. M., et al., "Advances in HTGR Fuel Performance Models," proceedings of BNES Conference on Nuclear Fuel Performance, Statford-Upon-Avon, March 21, 1985.

5. Alloway, R., et al., "HTGR Fuel Element Structural Design Considerations," Report No. GA-A18591 presented at IAEA Specialists' Meeting on Graphite Component Design, Tokaimura, Japan, September 8, 1986.

6. Breher, W., A. Neylan and A. Shenoy, "Modular HTGR Status," Paper at 22 nd IECEC, Philadelphia, Pa, August 10-14, 1987.

Work on this paper supported by DOE contract DE-AC03-845F11963. 